\title{
Introduction: Why Do We Need New Narratives for the History of the Federal Republic?
}

\author{
Frank Biess and Astrid M. Eckert
}

$\mathrm{O}$ BSERVERS of German current affairs and historians of contemporary Germany have long been cognizant of the shadow that the Nazi past and its crimes cast over postwar German history. Likewise, it has long been widely accepted as appropriate that the "old" Federal Republic would develop a political culture marked by reserve and modesty on the international stage and in its public representation-whatever seemed the opposite of the pomp, power, and ruthlessness of past German regimes. Whereas the prospect of unification in 1989-1990 still triggered concerns about the country's possible relapse into attitudes and behaviors worthy of a "fourth Reich," two decades later, Germans were treated to the news that theirs was "the most positively viewed nation in the world."1 A few years later still, German Chancellor Angela Merkel found herself widely hailed as the "leader of the free world," a phrase soaked in Cold War connotations and hitherto reserved for the president of the United States. ${ }^{2}$ Merkel probably had little desire for such a click-bait label; it was the world around her that had changed on the coattails of the global ascendancy of rightwing populism and authoritarianism, resulting, for example, in the British vote to leave the European Union ("Brexit"), the presidency of Donald Trump, and the attempt of the Polish government to do away with the separation of powers. With the strong showing of the right-wing Alternative for Germany (AfD) party in the 2017 federal elections, this development had begun to affect domestic politics in Germany as well. ${ }^{3}$

It is a truism that present concerns inform historical writing. This seems all the more applicable to the writing of "contemporary history" as the history of our own times. ${ }^{4}$ Yet, the recent tectonic shifts in the European and global political landscape have questioned assumptions about the stability of and consensus about the liberal democratic order that have long served as the normative framework for the historical interpretations of the Federal Republic. Arguably more than at any time since 1945, this framework and the certainties

\footnotetext{
${ }^{1}$ Tony Judt, Postwar: A History of Europe since 1945 (New York: Penguin, 2005), 639-40; Timothy Garton Ash, "The Chequers Affair," in History of the Present: Essays, Sketches, and Dispatches from Europe in the 1990s (New York: Random House, 1999), 50-56; “BBC Poll: Germany most popular country in the world," May 23, 2013 (http://www.bbc.com/news/world-europe-22624104). See also "Cool Germany. Germany is becoming more open and diverse," The Economist, April 14, 2018.

${ }^{2}$ See, e.g., Karl Vick, "2015 Person of the Year. Angela Merkel. Chancellor of the Free World," Time, Dec. 21, 2015.

${ }^{3}$ John Abromeit et al., eds., Transformations of Populism in Europe and the Americas (London: Bloomsbury, 2016); Cas Mudde, Populism: A Very Short Introduction (New York: Oxford University Press, 2017); JanWerner Müller, What is Populism? (Philadelphia: University of Pennsylvania Press, 2016); Timothy D. Snyder, The Road to Unfreedom: Russia, Europe, America (New York: Duggan Books, 2018).

${ }^{4}$ Hans Rothfels, "Zeitgeschichte als Aufgabe," Vierteljahrshefte für Zeitgeschichte 1, no. 1 (1953): 2.
} 
it provided have been called into question, setting the stage for the dire scenario that Dan Stone painted in his recent history of postwar Europe: the emergence of a "Europe of protectionist, nationalist micro-states led by populists demanding 'national preference,' but without the means to pay for it and unwilling to admit the foreign labor necessary to sustain it." 5 While historians of the Federal Republic had long celebrated the fact that "Bonn" had not become "Weimar," it now seems that, with only slight exaggeration, everybody else threaten to become "Weimar." It thus remains very much in doubt that the "global attraction of the ideas of 1776 and 1789" remains "unbroken," as Heinrich August Winkler was still asserting as recently as $2016 .^{7}$ Indeed, his publication one year later invoking the possible collapse of the West signaled that even its most ardent proponents have begun to doubt the idea of the West as the normative telos of contemporary history. Winkler now characterizes the election of Donald Trump as a calling into question of "nothing less than the normative project of the West." 8 Such pervasive uncertainty about the future of Western-style modernity strikes us as an important reason to think about possible new narratives for the history of the Federal Republic.

Any set of new narratives needs to engage with the established ones. The Federal Republic is, by now, the longest existing political formation in the history of modern Germany. By 2023, it will have lasted longer than the German Empire, the Weimar Republic, and the Third Reich combined. It is therefore not surprising that the Federal Republic not only has a history but also a substantial historiography. The development of this historiography was well underway during the 1980s, and it became deeply affected by the political caesura of 1989-1990. ${ }^{9}$ With the unexpected demise of the German Democratic Republic (GDR), the predominant focus immediately shifted to an analysis of East Germany, as historians encountered a once-in-a-lifetime triangular constellation: a political mandate to reckon with the past of the "second German dictatorship," concomitant public funding to do so, and dreamlike access to the files of a defunct state. ${ }^{10}$ The rush to historicize the GDR coexisted with an ongoing engagement with the history of the old Federal Republic-seen, for example, in two research clusters at the universities in Tübingen and Freiburg, which focused respectively on the "Westernization" and "liberalization" of the pre-1990 Federal Republic. ${ }^{11}$ The 1990 s also constituted a gestation period because any sense that the "old"

\footnotetext{
${ }^{5}$ Dan Stone, Goodbye to All That? The Story of Europe since 1945 (New York: Oxford University Press, 2014), 294.

${ }^{6}$ See, e.g., Roger Cohen, “Trump's Weimar America,” New York Times, Dec. 14, 2016.

${ }^{7}$ Heinrich August Winkler, Geschichte des Westens. Bd. 4: Die Zeit der Gegenwart (Munich: C. H. Beck, 2016), 610.

${ }^{8}$ Heinrich August Winkler, Zerbricht der Westen? Über die gegenwärtige Krise in Europa und Amerika (Munich: C. H. Beck, 2017), 11.

${ }^{9}$ Influential markers of this emerging historiography before 1989 were Christoph Kleßmann, Die doppelte Staatsgründung. Deutsche Geschichte 1945-1955 (Bonn: Bundeszentrale für politische Bildung, 1986), as well as Karl Dietrich Bracher, Theodor Eschenburg, Joachim C. Fest, and Eberhard Jäckl, eds., Geschichte der Bundesrepublik Deutschland, 1945-1982, vols. 1-5. (Stuttgart: DVA, 1983-1987). A sixth volume was added in 2000: Andreas Wirsching, Abschied vom Provisorium, 1982-1990 (Stuttgart: DVA, 2000).

${ }^{10}$ The very title of Klaus-Dietmar Henke, ed., Wann bricht schon mal ein Staat zusammen! Die Debatte über die Stasi-Akten und die DDR-Geschichte auf dem 39. Historikertag 1992 (Munich: dtv, 1993) nicely captures the professional excitement about exploring the history of the GDR.

${ }^{11}$ The research clusters were located at the University of Tübingen (1992-1996) and at the University of Freiburg (1997-2000). See Anselm Doering-Manteuffel, Wie westlich sind die Deutschen? Amerikanisierung und Westernisierung im 20. Jahrhundert (Göttingen: Vandenhoeck \& Ruprecht, 1999), 135; Ulrich Herbert, ed.,
} 
Federal Republic had also encountered a major caesura in 1989-1990 and was turning into a concluded historical epoch was slow in forming. Because the West German political, economic, and constitutional framework persisted into unified Germany, East Germans bore the brunt of the transformative changes of the 1990s. Depending on where they lived and what they did for a living, many West Germans, by contrast, had the chance to pretend that "their" country had hardly been affected by the profound changes that Germany as a whole was undergoing. The idea that both East and West Germany were experiencing a "co-transformation" during the 1990s is, in fact, of recent vintage. ${ }^{12}$

The turn of the century saw the beginning of a publication of new syntheses of the Federal Republic's history, which suggested that historians increasingly viewed the history of the "old" Federal Republic as a distinct historical period that could be narrated in a longitudinal analysis covering the entire period from the end of World War II to the fall of the Berlin Wall. ${ }^{13}$ This development was abetted by the anniversaries of the Federal Republic: the fiftieth in 1999 and, ten years later, the sixtieth, combined with a celebration of twenty years of unification. ${ }^{14}$ Beginning their lives as lengthy essays, these books on the Federal Republic soon assumed the heft and scope of traditional national histories. ${ }^{15}$ They shared a desire to reevaluate that history, now that one of the purposes of the state's founding-overcoming partition - had been achieved. A vivid debate about how the Federal Republic should be historicized accompanied the appearance of these histories. ${ }^{16}$

Wandlungsprozesse in Westdeutschland. Belastung, Integration, Liberalisierung 1945-1980 (Göttingen: Wallstein, 2002), 587.

${ }^{12}$ Philipp Ther, Europe since 1989: A History, trans. Charlotte Hughes-Kreutzmüller (Princeton, NJ: Princeton University Press, 2016); Thomas Großbölting and Christoph Lorke, eds., Deutschland seit 1990. Wege in die Vereinigungsgesellschaft (Stuttgart: Steiner, 2017). See also Frank Bösch, "Divided and Connected: Perspectives on German History since the 1970s," in A History Shared and Divided: East and West Germany since the 1970s, ed. Frank Bösch, trans. Jennifer Walcoff Neuheiser (New York: Berghahn, 2018), 7-8.

${ }^{13}$ Paul Nolte, "Die Bundesrepublik in der deutschen Geschichte des 20. Jahrhunderts," Geschichte und Gesellschaft 28, no. 2 (2002): 175.

${ }^{14}$ Gabriele Metzler, "Zu neuen Ufern? Die Zeitgeschichtsschreibung zur Bundesrepublik im Jubiläumsjahr 2009," Neue Politische Literatur 57 (2012): 233.

${ }^{15}$ The lengthy essays include Gerhard A. Ritter, Über Deutschland. Die Bundesrepublik in der deutschen Geschichte (Munich: C. H. Beck, 1998); Doering-Manteuffel, Wie westlich sind die Deutschen; Axel Schildt, Ankunft im Westen. Ein Essay zur Erfolgsgeschichte der Bundesrepublik (Frankfurt/Main: Fischer, 1999), 11, 20. The national histories include Winkler, Der lange Weg nach Westen; Edgar Wolfrum, Die geglückte Demokratie. Geschichte der Bundesrepublik von ihren Anfängen bis zur Gegenwart (Stuttgart: Klett-Cotta, 2006); Manfred Görtemaker, Geschichte der Bundesrepublik Deutschland. Von der Gründung bis zur Gegenwart (Frankfurt/Main: Fischer, 2004); Konrad H. Jarausch, After Hitler: Recivilizing Germans, 1945-1995, trans. Brandon Hunziker (New York: Oxford University Press, 2006); Hans-Ulrich Wehler, Deutsche Gesellschaftsgeschichte. Fünfter Band: Bundesrepublik und DDR 1949-1990 (Munich: C. H. Beck, 2008); Eckart Conze, Die Suche nach Sicherheit. Eine Geschichte der Bundesrepublik von 1949 bis in die Gegenwart (Munich: Siedler, 2009); Ulrich Herbert, Geschichte Deutschlands im 20. Jahrhundert (Munich: C. H. Beck, 2014).

${ }^{16}$ See, e.g., Klaus Naumann, "Die Historisierung der Bonner Republik," Mittelweg 369, no. 3 (2000): 5367; Axel Schildt, "Überlegungen zur Historisierung der Bundesrepublik," in Verletztes Gedächtnis. Erinnerungskultur und Zeitgeschichte im Konflikt, ed. Konrad H. Jarausch and Martin Sabrow (Frankfurt/ Main: Campus, 2002), 253-72; idem, "Fünf Möglichkeiten, die Geschichte der Bundesrepublik zu erzählen," Blätter für deutsche und internationale Politik 44, no. 10 (1999), 1234-44; Nolte, "Bundesrepublik"; Konrad H. Jarausch and Martin Sabrow, eds., Die historische Meistererzählung: Deutungslinien der deutschen Nationalgeschichte nach 1945 (Göttingen: Wallstein, 2002). 
Such reflections betrayed a palpable unease that the histories of the Federal Republic available in the early twenty-first century had fallen into certain interpretative and narrative tracks, according to which the Federal Republic had arisen from the moral and physical devastation of the Nazi years through a process of democratization, liberalization and Westernization-culminating in the "gift of German unity," which had restored the nation-state. The role of the GDR in these histories was usually marginal, serving mainly as the Cold War sparring partner of a West Germany that would ultimately prevail. Indeed, some of these books were not free of a certain triumphalism about the GDR's demise and the persistence of the Federal Republic as the only German state. In one of his trademark provocations, Hans-Ulrich Wehler famously reduced the GDR to a "Soviet satrapy," relegating it to a footnote in postwar German history. ${ }^{17}$

Early reservations about the post-unification crop of histories of the Federal Republic have been fleshed out more recently in combination with a set of alternative perspectives. The confluent publication of several edited collections during the last half-decade indicates that a collective search, or grappling, is underway, one that displays some dissatisfaction with established narratives produced in the 1990s and 2000s but that has not yet arrived at a new synthesis. ${ }^{18}$ These volumes seek to widen the historiographical lens by putting the history of the Federal Republic in conversation with parallel or divergent developments in other national histories, mainly in Western Europe and the United States, to a lesser extent in Eastern Europe, yet rarely with respect to the Global South. Whereas some call for placing the history of the Federal Republic in new spatial relationships, others seek to interrogate the crucial transformation of 1970s as a new Sattelzeit transcending the 1989-1990 caesura.

This special issue joins that conversation. The proliferating search for new narratives of the history of the Federal Republic points to a widespread perception on both sides of the Atlantic that the established ones are no longer fully persuasive. This can perhaps be described as a deconstructive moment in a Kuhnian paradigm shift, i.e., a period when established paradigms lose traction, though a new paradigm has not yet emerged. What, then, are the sources of historiographical dissatisfaction with these established narratives? What underlies contemporary efforts to challenge the "master narrative(s)" of the Federal Republic that constituted the consensus of the early 2000s? This introduction identifies some aspects of the established narratives that appear less likely to generate new perspectives, and it suggests a set of new questions and perspectives that, we believe, might inform future narratives of the history of the Federal Republic.

The most obvious feature of the extant historiography on the Federal Republic is the emphasis on its "success." It is hard to overstate the degree to which this focus on the Federal Republic's accomplishments has shaped historical writing on West Germany. The success narrative initially served the needs of self-affirmation while supporting the respective political status quo. It focused on the stability of new democratic institutions

\footnotetext{
${ }^{17}$ Wehler, Deutsche Gesellschaftsgeschichte, xv-xvi, 424-25. Just how incisive Wehler's provocation really was can be seen in Patrick Bahners and Alexander Cammann, eds., Bundesrepublik und DDR. Die Debatten um Hans-Ulrich Wehlers 'Deutsche Gesellschaftsgeschichte' (Munich: Beck'sche Reihe, 2009), 73-106.

${ }^{18}$ Bösch, A History Shared and Divided; Alexander Gallus, Axel Schildt, and Detlef Siegfried, eds., Deutsche Zeitgeschichte - transnational (Göttingen: Wallstein, 2015); Sonja Levsen and Cornelius Torp, eds., Wo liegt die Bundesrepublik? Vergleichende Perspektiven auf die westdeutsche Geschichte (Göttingen: Vandenhoeck \& Ruprecht, 2016); Frank Bajohr, Anselm Doering-Manteuffel, Claudia Kemper, and Detlef Siegfried, eds., Mehr als eine Erzählung. Zeitgeschichtliche Perspektiven auf die Bundesrepublik (Göttingen: Wallstein, 2016).
} 
and politics, economic recovery, and newfound prosperity, and it depicted the Federal Republic as a "phoenix [rising] from the ashes." ${ }^{19}$ The success paradigm has proven to be inescapable and continues to reverberate in recent histories of the Federal Republic. For Edgar Wolfrum, the Federal Republic constitutes a "stroke of luck" (Glücksfall), a "successful and respected democracy" that has proven to be a "prosperous society capable of reform." 20 Manfred Görtemaker praised the Federal Republic's “astounding stability," and Hans-Ulrich Wehler called it an "astonishing success story" that shines "all the more brightly" when contrasted with the Nazi years. ${ }^{21}$ For Ulrich Herbert, "the slow transformation of a society shaped by National Socialism into a liberal Western society, as is the case with the Federal Republic, is one of the most remarkable developments of this century."22

This paradigm of a successful postwar transformation has a strong generational imprint. Historians such as Wehler (1930-2014), Wolfgang Mommsen (1930-2004), Hans Mommsen (1930-2015), and Gerhard A. Ritter (1929-2015), as well as Heinrich August Winkler and Volker Berghahn (both born in 1938), Konrad Jarausch and Jürgen Kocka (both born in 1941), all belong or belonged to a cohort that shared the "experiential matrix" of National Socialism, the collapse of the Third Reich, and the ensuing Allied occupation. As a new West German state emerged from dictatorship and war, they shared an affirmative attitude toward the Federal Republic and were "committed to a democratic and republican system of government, even if they disagreed about its precise meaning." 23 Their "emphatic identification with the constitution and political order of the Federal Republic," as Paul Nolte puts it, came to constitute the conceptual vanishing point of their academic work, and it was only reinforced by their persistent doubts about the political stability of the West German state and its ability to defend its liberal accomplishments against challenges from both the Left and the Right. ${ }^{24}$ Their appreciation and admiration for Western liberal democracy also resulted from a common biographical fact: many of these historians spent what Hans-Ulrich Wehler once fondly recalled as "formative and personally, as well as academically, happy years" in the United States or in Great Britain, or at least maintained close personal relationships with British and American scholars. ${ }^{25}$

To be sure, none of these historians' early works focused on the history of the Federal Republic, a state that was still too young to historicize when they embarked on their academic careers. Rather, the project of this generation was to explain the rise of Nazism out of the flaws of the German Empire and the Weimar Republic. Yet, the Federal Republic often featured as an implicit counterpoint to the crises and catastrophes of these earlier time periods in German history. Indeed, it came to represent the positive foil to the thesis

\footnotetext{
${ }^{19}$ Wolfrum, Die geglückte Demokratie, 13; also see Schildt, “Überlegungen,” 260-61.

${ }^{20}$ Wolfrum, Die geglückte Demokratie, 18.

${ }^{21}$ Görtemaker, Bundesrepublik, 13; Wehler, Deutsche Gesellschaftsgeschichte, 425, 427.

${ }^{22}$ Herbert, Geschichte Deutschlands im 20. Jahrhundert, 16.

${ }^{23}$ A. Dirk Moses, German Intellectuals and the Nazi Past (New York: Cambridge University Press, 2007), 57, 64-65.

${ }^{24}$ Paul Nolte, “Die Historiker der Bundesrepublik. Rückblick auf eine 'lange Generation,”" Merkur 53, no. 5 (1999): 426. On the concept of vanishing points, see Helmut Walser Smith, "The Vanishing Point: An Essay on Perspective," History \& Memory 17, no. 1/2 (2005): 269-95; on the political fears of the "Fortyfivers" generation, see Moses, German Intellectuals.

${ }^{25}$ Quotation in Paul Nolte, Hans-Ulrich Wehler. Historiker und Zeitgenosse (Munich: C. H. Beck, 2015), 51; Philipp Stelzel, History after Hitler: A Transatlantic Enterprise (Philadelphia: University of Pennsylvania Press, 2019), 91-105.
} 
of the German Sonderweg, i.e., Germany's supposed deviation from a Western path to modernity, which featured so prominently in the work of these historians. In that sense, the success of the Federal Republic constituted both the "negation and the last chapter" of the Sonderweg historiography, powerfully exemplified in Hans-Ulrich Wehler's fifth and final volume of his Deutsche Gesellschaftsgeschichte. ${ }^{26}$ The Federal Republic's success became, as Sonja Levsen and Cornelius Torp have written, a "complementary narrative" that offered "a happy end to the thesis of a German 'Sonderweg." 27

Most historians of the Federal Republic simply could not avoid the success paradigm. Axel Schildt described it as almost "too good to be true," but he also declared that any effort to "diminish or relativize" the undeniable achievements of the Federal Republic could not be taken seriously. ${ }^{28}$ There are, therefore, good reasons why the emplotment of the country's history as a "success story" (or "romance," in Hayden White's terms) continues to be so deeply embedded in the historiography. ${ }^{29}$ The contribution of some of the works published around 2000 was, however, that they no longer treated the Federal Republic's success as an unquestioned assumption. Rather, these histories - and many of the more specialized monographs on which they built-demanded an explanation for the fundamental transformation that had turned a post-fascist state into a functioning liberal democracy. This historiography became productive because it shifted the focus from diplomatic history, political institutions, and "great men" like Konrad Adenauer to less tangible processes of internal democratization and shifts in values. It brought into focus what Konrad H. Jarausch has called the "incremental changes in the beliefs and behaviors that shape everyday life," which were central to the inner transformation of the Federal Republic. ${ }^{30}$ This literature analyzed fundamental changes in political engagement, in patterns of consumption, in business culture, in social values, and in the country's relationship to its criminal Nazi past - without any of the violent upheavals that had previously defined German history. ${ }^{31}$

The historiography of the Federal Republic's transformation became one of the most vibrant fields in German historiography. These narratives significantly broadened our understanding of the Federal Republic's postwar history and constituted the history of West Germany as a historiographical field in its own right. But they did not diverge fundamentally from previous models of the Federal Republic as the counterpoint to the Sonderweg. Instead, they provided rich empirical and historiographical substantiation of this thesis. As the grammatical form of conceptual paradigms such as "Westernization," "liberalization," "Americanization," or "recivilization" indicated, they always entailed a deterministic thrust and telos: the Federal Republic's eventual "arrival" in the fold of Western liberal democracies. Implicitly or (as in Winkler's case) explicitly, the Federal Republic was cast as the last stage in Germany's "long path to the West." 32 This

\footnotetext{
${ }^{26}$ A. Dirk Moses, "The 'Weimar Syndrome' in the Federal Republic of Germany. The Carl Schmitt Reception by the Forty-Fiver Generation of Intellectuals," in Leben, Tod und Entscheidung. Studien zur Geistesgeschichte der Weimarer Republik, ed. Stephan Loos (Berlin: Duncker \& Humblot, 2003), 207.

${ }^{27}$ Sonja Levsen and Cornelius Torp, "Die Bundesrepublik und der Vergleich," in Levsen and Torp, Wo liegt die Bundesrepublik?, 14.

${ }^{28}$ Schildt, "Überlegungen," 260; this is repeated almost verbatim in Wolfrum, Die geglückte Demokratie, 13.

${ }^{29}$ See Hayden White, Metahistory: The Historical Imagination in Nineteenth-Century Europe (Baltimore, MD: John Hopkins University Press, 1973), 8-9 (cited in Joachim Häberlen's contribution to this special issue).

${ }^{30}$ Jarausch, After Hitler, vii.

${ }^{31}$ As a benchmark volume in this respect, see Herbert, Wandlungsprozesse.

${ }^{32}$ For the argument that the "anti-Western special path" ended in 1945, and the "post-national special path" of the Federal Republic in 1990, see Winkler, Der lange Weg nach Westen, 2:655.
} 
gradual "Westernization" constituted, in the eyes of Anselm Doering-Manteuffel and his collaborators, the Federal Republic's most important achievement. ${ }^{33}$

Because this interpretation of the Federal Republic's history was so closely tied to the Sonderweg interpretation, the historiographical critique of the latter, which was well underway by the 1980s and 1990s, needs to be extended to the post-1945 period as well. In the epilogue to his magisterial Deutsche Gesellschaftsgeschichte, Hans-Ulrich Wehler openly conceded the "undeniably Eurocentric orientation" of his approach. But he justified this by refering to the experiences of his generation: "under the biographical impression of war and dictatorship, the Western path was sugarcoated [beschönigt]" for the sake of argument, i.e., to achieve a "clear contrast." 34 Yet, if the history of the Federal Republic is written as the history of a gradual convergence with the West, then it seems appropriate to subject this historiography to similar empirical tests and criticisms as the Sonderweg thesis, on which the conceptual framework of the Westernization narrative ultimately rests. The "special path" argument eventually lost traction thanks to comparative research contrasting German developments with idealized Western models, leading Levsen and Torp to propose testing the "success narrative" of the Federal Republic through comparison as well. ${ }^{35}$ Along similar lines, Riccardo Bavaj and Martina Steber have called for historicizing "the very process of 'Western' identityshaping" in German history. The contributors to a volume that they edited trace changing German notions and discursive constructions of "the West" that Germans either rejected or embraced, from the eighteenth to the twentieth century. ${ }^{36}$ The "West" does not appear here as an idealized vanishing point of modern German history but rather as a historical construct - one to which Germans related in historically changing and specific ways.

The problem with the "Westernization" narrative is not just the degree to which "the West" that the Federal Republic eventually joined had been idealized. The unquestioned acceptance of the West as a normative framework has also oddly decoupled the history of the Federal Republic from a historiography that has critically interrogated the failed promises, contradictions, multiple exclusions, and sheer violence of the so-called Western liberal tradition. In addition, "Westernization" as a framework for the postwar history of the Federal Republic has difficulties accounting for the continued existence and powerful presence of authoritarian and illiberal traditions in the West, not least in recent years with "Brexit" and the election and policies of Trump. ${ }^{37}$ Whereas David Blackbourn and Geoff

\footnotetext{
${ }^{33}$ Doering-Manteuffel, Wie westlich sind die Deutschen.

${ }^{34}$ Wehler, Deutsche Gesellschaftsgeschichte, 422, 425.

${ }^{35}$ Richard J. Evans, "Whatever became of the Sonderweg?," in Rereading German History, 1800-1996: From Unification to Reunification (London: Routledge, 1997), 12-22; Levsen and Torp, "Die Bundesrepublik und der Vergleich," 9, 16.

${ }^{36}$ Riccardo Bavaj and Martina Steber, eds., Germany and "The West": The History of a Modern Concept (New York: Berghahn, 2015), 4.

${ }^{37}$ This is true despite early critiques; see, e.g., Mary Nolan, "Americanization or Westernization," paper presented at the conference "The American Impact on Western Europe: Americanization and Westernization in Transatlantic Perspective," German Historical Institute Washington, D.C., March 25-27, 1999 (webdoc.sub.gwdg.de/ebook/p/2005/ghi_12/www.ghi-dc.org/conpotweb/westernpapers/nolan.pdf). On the ways in which anti-liberalism was deeply rooted in European history, see Mark Mazower, Dark Continent: Europe's Twentieth Century (New York: Vintage, 2000). At a minimum, histories of "Westernization" and "liberalization" would have to reflect on the ways in which Western liberalism served to justify colonialism. See, e.g., Jennifer Pitts, A Turn to Empire: The Rise of Imperial Liberalism in Britain and France (Princeton, NJ: Princeton University Press, 2005). On the difficulty of separating the "West" from the "legacies of slavery and racism," see Konrad H. Jarausch, "The Federal Republic at
} 
Eley emphasized Imperial Germany's relative similarity to other Western nations in their influential deconstruction of the Sonderweg thesis, the same approach, when applied to the Federal Republic, suggests a need to investigate the ways in which it shared in the more problematic aspects of that tradition. ${ }^{38}$ Asking how the Federal Republic partook in or was exposed to its contradictions, exclusions, and repressive aspects should not be written off as "postmodern, seemingly liberal arbitrariness [Beliebigkeit]," as Winkler has suggested. ${ }^{39}$ Rather, a failure to do so will result in a history that is, at best, incomplete and, at worst, distorted.

It is, for instance, standard practice in the historiography to credit the Western allies, especially the United States, with the Federal Republic's successful long-term democratization. ${ }^{40}$ Yet, syntheses of the history of the Federal Republic hardly ever address the fact that the American occupying army, deeply shaped by a long tradition of institutionalized racism, remained officially racially segregated until 1948. American occupation officials in Berlin such as Edgar Johnson, the advisor to General Lucius D. Clay, frequently commented on racism in the US army in Germany; Rainer Werner Fassbinder famously depicted it in the 1979 film The Marriage of Maria Braun; and several American scholars have made it a central theme in their histories of the American occupation of Germany. ${ }^{41}$ One can also point to the extent to which the Western liberal model was predicated on a hierarchical gender order, as well as on heterosexual normativity. Here, too, American scholars such as Robert G. Moeller and others have offered important critical perspectives informed by gender and queer history. These approaches complicate the dominant narratives of gradual convergence with the West as one of liberal emancipation from an authoritarian past by pointing to repressive and exclusionary features within the Western liberal tradition itself. ${ }^{42}$

Sixty: Popular Myths, Actual Accomplishments, and Competing Interpretations," German Politics and Society 28, no. 94 (2010): 22. Michel Foucault's lectures on the Federal Republic in the 1970s might be another starting point for criticism of Western liberalism. See Michel Foucault, The Birth of Biopolitics: Lectures at the College de France 1978-79, trans. Graham Burchell. (New York: Palgrave, 2008), 75-157.

${ }^{38}$ David Blackbourn and Geoff Eley, The Peculiarities of German History: Bourgeois Politics and Society in Nineteenth Century Germany (New York: Oxford University Press, 1984).

${ }^{39}$ Winkler, Der lange Weg nach Westen, 2:ix.

${ }^{40}$ See, e.g., Wehler, Deutsche Gesellschaftsgeschichte, 3, 19; Klaus-Dietmar Henke, Die amerikanische Besetzung Deutschlands (Munich: R. Oldenbourg, 1995); Hermann-Josef Rupieper, Die Wurzeln der westdeutschen Nachkriegsdemokratie. Der amerikanische Beitrag (Opladen: Westdeutscher Verlag, 1993); Jarausch, After Hitler, 19-95.

${ }^{41}$ Werner Breunig and Jürgen Wetzel, eds., Fünf Monate in Berlin. Briefe von Edgar N. Johnson aus dem Jahre 1946 (Munich: Oldenbourg/de Gruyter, 2014); Maria Höhn, GIs and Fräuleins: The German-American Encounter in 1950s West Germany (Chapel Hill: University of North Carolina Press, 2002); Heide Fehrenbach, Race after Hitler: Black Occupation Children in Postwar Germany and America (Princeton, NJ: Princeton University Press, 2005); Timothy L. Schroer, Recasting Race After World War II: Germans and African Americans in American-Occupied Germany (Boulder: University Press of Colorado, 2007). For France, see Mary L. Roberts, What Soldiers Do: Sex and the American GI in World War II France (Chicago, IL: University of Chicago Press, 2013).

${ }^{42}$ Robert G. Moeller, Protecting Motherhood: Women and the Family in the Politics of Postwar West Germany (Berkeley: University of California Press, 1993); idem, “The Homosexual Man is a 'Man,' the Homosexual Woman is a 'Woman': Sex, Society, and the Law in Postwar West Germany," Journal of the History of Sexuality 4, no. 3 (1994): 395-429; Elizabeth Heineman, What Difference Does a Husband Make? Women and Marital Status in Nazi and Postwar Germany (Berkeley: University of California Press, 1999). See also Jennifer Evans, ”Why Queer German History?," German History 34, no. 1 (2016): 371-84 
Even the more basic task of writing women as actors into the history of the Federal Republic remains only partly fulfilled, despite a rich monographic literature on the subject. ${ }^{43}$ For example, "1968," the cluster of events commonly credited for having broken with Germany's authoritarian past and allowed for cultural liberalization, has entered the historiography as a male-centered narrative. As Christina von Hodenberg shows in her contribution to this special issue, female student activists such as Helke Sander, Sigrid Damm-Rüger, Silvia Bovenschen, Sarah Haffner, Frigga Haug, Karin Adrian, and Florence Hervé never made it into analyses of "1968," let alone into survey texts of the Federal Republic. At issue is not merely a recognition of women as more than, in Hodenberg's phrase, the "arm candy" of male protagonists during the student protests. Rather, the gendered myths about "1968" have facilitated a misleading explanation of the upheaval as a clash between Nazi fathers taken to task by their antifascist sons, a depiction that is not only inaccurate but had also left no space for women in the first place. Ultimately, von Hodenberg suggests, the long-term impact of female '68ers was arguably more significant than that of their male confrères.

Perhaps the most serious shortcoming of the established master narrative of the Federal Republic, and of many of the syntheses cited earlier, is their conceptual inability to deploy "race" as an analytical category. Both Rita Chin and Michael Meng have underlined the political and analytical costs of not engaging the categories of "race" and "racism" when analyzing German postwar attitudes toward ethnic others, such as guest workers or asylum seekers. ${ }^{44}$ As Anthony Kauders has demonstrated, the history of the Federal Republic looks different as well from the perspective of its German-Jewish minority. ${ }^{45}$ Greater attention to "race" as an analytical category might thus provide an opportunity for understanding the historical genesis of what Ulrich Herbert has called "the ugly face of the new Germany," as manifested in the treatment of refugees, asylum seekers, and ethnic others. ${ }^{46}$ Lauren Stoke's essay in this issue demonstrates how the history of the Federal Republic shifts significantly if one places "refugees at the center." She traces the historical precursors of the most recent "refugee crisis" and demonstrates that the confrontation with repeated episodes of forced migration-involving so-called displaced persons, refugees from East Germany, guest workers, or asylum seekers—was "structurally constitutive" for the history of the Federal Republic.

Beyond this issue of "race" and immigration, the separation of the history of the Federal Republic from critical approaches to the Western tradition, such as postcolonialism, has further obscured the legacies of colonialism and colonial wars in the history of West Germany. To be sure, individual studies have begun to incorporate postcolonial perspectives

\footnotetext{
${ }^{43}$ This literature goes back to Ute Frevert, Frauen-Geschichte. Zwischen Bürgerlicher Verbesserung und Neuer Weiblichkeit (Frankfurt/Main: Suhrkamp, 1986). For a more recent overview, see Karen Hagemann and Jean Quataert, eds., Gendering Modern German History: Rewriting History (New York: Berghahn, 2007).

${ }^{44}$ Rita Chin, "Thinking Difference in Postwar Germany: Some Epistemological Obstacles around 'Race," in Migration, Memory, and Diversity: Germany from 1945 to the Present, ed. Cornelia Wilhelm (New York: Berghahn), 206-29; Michael Meng, "Silences about Sarrazin's Racism in Contemporary Germany," Journal of Modern History 87, no. 1 (2015): 102-35.

${ }^{45}$ Anthony Kauders, Unmögliche Heimat. Eine deutsch-jüdische Geschichte der Bundesrepublik (Munich: DVA, 2007).

${ }^{46}$ Ulrich Herbert, “Ausländer-Asyl-Pogrome. Das hässliche Gesicht des neuen Deutschlands," in Bajohr et al., Mehr als eine Erzählung, 145-55.
} 
into that history. ${ }^{47}$ But these insights have not yet been incorporated into the established master narratives. It is not clear, for example, whether and how a "self-reflexive use of the concept of 're-civilization,"' as suggested by Konrad Jarausch, can rescue the concept from its deep implication in legitimizing Western colonialism. ${ }^{48}$ Histories of the Federal Republic also rarely address the implications of the colonial wars fought by West Germany's allies, which drew the Federal Republic into the processes of decolonization through economic ties or even arms sales. They only begin to engage the ways in which the Federal Republic participated in the complicated legacy of unequal relationships to the Global South, whether through its own development work or the group of European economic institutions that tied French and Belgian possessions in Africa to the Common Market. ${ }^{49}$ The new narratives of the Federal Republic would do well not to accept uncritically the normative assumptions of the "West" as an unquestionably beneficent model that always generated self-correcting impulses, and to reflect on the problematic aspects of that tradition as well. This seems all the more important at a moment when some of the foundations of the "liberal West" appear to be shifting.

Incorporating postcolonial approaches into the history of the Federal Republic would also open up the field to more transnational perspectives. Indeed, one of the challenges for new narratives will be to take more seriously the insight that much of postwar German history took place outside the national boundaries of the Federal Republic —or, as Lutz Raphael has put it, to engage in the search "for German places in a more integrated, globalized world." 50 In light of the Federal Republic's overwhelming orientation toward its Western European neighbors, a Europeanization of West German history seems particularly important. ${ }^{51}$ To that end, Karrin Hanshew reveals in this issue the analytic potential of an "entangled history" involving both postwar Germanys and Italy that moves beyond more traditional national comparisons. She also shows how German-Italian interaction shaped postwar national (and European) identities in a "mutually constitutive way."

At the same time, it is also important to ask what remained nationally specific in the history of the Federal Republic —or, to modify Lutz Raphael's question, to search for "German" places in a more integrated, globalized Germany. Such a transnational approach

\footnotetext{
${ }^{47}$ Young-Sun Hong, Cold War Germany, the Third World, and the Global Humanitarian Regime (Cambridge: Cambridge University Press, 2015); Quinn Slobodian, Foreign Front: Third World Politics in Sixties West Germany (Durham, NC: Duke University Press, 2012); Manuel Borutta and Jan C. Jansen, eds., Vertriebene and pieds-noirs in postwar Germany and France: Comparative Perspectives (Basingstoke: Palgrave Macmillan, 2016).

${ }^{48}$ Jarausch, "The Federal Republic at Sixty," 22. See also Jarausch, After Hitler, 10-14. On the critique of civilizational narratives, see Dipesh Chakrabarty, Provinicializing Europe: Postcolonial Thought and Historical Difference (Princeton, NJ: Princeton University Press, 2007), 27-71.

${ }^{49}$ Peo Hansen and Stefan Jonsson, "Eurafrica Incognita: The Colonial Origins of the European Union," History of the Present 7, no. 1 (2017): 1-32; William Glenn Gray, "Waffen aus Deutschland? Bundestag, Rüstungshilfe und Waffenexport 1961-1975," Vierteljahrshefte für Zeitgeschichte 64, no. 2 (2016): 327-64; Mathilde von Bülow, West Germany, Cold War Europe and the Algerian War (Cambridge: Cambridge University Press, 2016); Agnes Bresselau von Bressendorf, Elke Seefried, and Christian F. Ostermann, eds., West Germany, the Global South, and the Cold War (Berlin: de Gruyter, 2017); Hubertus Büschel, Hilfe zur Selbsthilfe. Deutsche Entwicklungsarbeit in Afrika 1960-1975 (Frankfurt/Main: Campus, 2014).

${ }^{50}$ Lutz Raphael, "Die Geschichte der Bundesrepublik schreiben als Globalisierungsgeschichte. Oder die Suche nach deutschen Plätzen in einer zusammenrückenden Welt," in Bajohr et al., Mehr als eine Erzählung, 203-18.

${ }^{51}$ Jarausch, “The Federal Republic at Sixty,” 22-23.
} 
might also distinguish what was distinctly "German" about the anti-nuclear movement, for example, or about left-wing terrorism in the Federal Republic. ${ }^{52}$ The new attention to the transnational dimensions of postwar German history should not come at the expense of sensitivity to its distinct national peculiarities. After all, national belonging remained a constant point of reference by which many postwar Germans defined their subjectivity: either as a central, even existential aspect of their identity or, for that matter, as a negative predicament to be avoided at all costs (by, for example, enthusiastically becoming European or “cosmopolitan").

What arguably set apart the history of the Federal Republic from other national histories were the legacies of the Nazi dictatorship and the Holocaust. It is perhaps only a slight polemical exaggeration to argue that that real Sonderweg began in 1945. Few other societies needed to confront a similar political and moral collapse as Germany did in 1945; and few other societies had to cope with a similar experience of violence, mass death, and mass murder as postwar Germany. Its post-fascist dimension thus gave the history of the Federal Republic its national distinctiveness. ${ }^{53}$ The country's comprehensive commemorative culture is a reflection of these peculiar national conditions. It has become a central aspect of German civic culture and national identity. Fueled by the boom in memory studies from the 1980s onward, the confrontation of the Federal Republic with the National Socialist past now counts as one of the most well-researched areas in memory studies more broadly. ${ }^{54}$ The notion of West German history as a "Belastungsgeschichte" — as a history "burdened by the past" - has been one of the main thrusts of the historiography. ${ }^{55}$ Although the scholarship on structural, ideological, and personnel continuities between the Nazi regime and the early Federal Republic brought to the fore the many deficits and delays in acknowledging the nature and extent of the crimes and in bringing perpetrators to justice, these shortcomings could be brushed aside as a necessary, if regrettable, functional requirement of a democratizing society. ${ }^{56}$ Indeed, these very deficits became compatible with the success paradigm when historians recast the rocky road of "coming to terms" with the Nazi past as an integral element of the Federal Republic's gradual and successful democratization. ${ }^{57}$

Newer approaches will not have to deconstruct this story entirely, and they should give due recognition to the achievements of West German commemorative culture. Blind spots do remain, however. The Federal Republic does not face an onslaught of populist antifascism to the same extent as France, Poland, and Hungary do, but the existence of persistent rightwing and neo-Nazi traditions in Germany should not be minimized. As several studies have shown, blatantly apologetic and revisionist memories of its Nazi past have accompanied the Federal Republic from the beginning and have constantly sought to push the discursive

\footnotetext{
${ }^{52}$ See Andrew S. Tompkins, Better Active than Radioactive: Anti-Nuclear Protest in 1970s France and West Germany (Oxford: Oxford University Press, 2016); Petra Terhoeven, Deutscher Herbst in Europa. Der Linksterrorismus der siebziger Jahre als transnationales Phänomen (Munich: Oldenbourg, 2014). On the interaction between globalization and nationalism, still unsurpassed is Sebastian Conrad, Globalization and the Nation in Imperial Germany, trans. Sorcha O’Hagan. (Cambridge: Cambridge University Press, 2010).

${ }^{53}$ Conze, Die Suche nach Sicherheit, 14.

${ }^{54}$ Robert G. Moeller, "What Has Coming to Terms with the Past Meant in the Federal Republic of Germany?," Central European History 35, no. 2 (2002): 223-56.

${ }^{55}$ Schildt, "Fünf Möglichkeiten," 265-68.

${ }^{56}$ For the classic statement of this argument, see Hermann Lübbe, "Der Nationalsozialismus im deutschen Nachkriegsbewusstsein," Historische Zeitschrift 236, no. 1 (1983): 579-99.

${ }^{57}$ Jarausch, After Hitler.
} 
boundaries of legitimate (and legal) public discourse. ${ }^{58}$ The recent electoral success of the extreme right-wing AfD similarly reflects the desire for historical revisionism among at least a segment of the German population. The editors of a 2008 volume thus contend that the "deficits in coming to terms with the past run counter to the success story," and that the "political and ideological rootedness of the Nazi regime in German society was much deeper than previous research has recognized"-although the existing historiography probably addressed these "deficits" to a greater extent than these scholars are willing to concede. ${ }^{59}$ An entire series of studies on state bureaucracies has recently demonstrated that virtually every segment of the postwar West German state was somehow implicated in the Nazi past and its legacies. ${ }^{60}$

Moreover, the significance of a specifically German commemorative culture focusing on the national past in an increasingly multicultural society remains unclear. The extensive historiography on coming to terms with the Nazi past, including racially motivated war and genocide, stands in odd contrast to the reluctance of historians of West Germany to engage the categories of racial or ethnic difference in that society. Rita Chin has argued, in fact, that the advances in Holocaust memory actually contributed to more restrictive definitions of Germanness that eventually excluded non-German immigrants. ${ }^{61}$ Holocaust memory has thus tended to reinforce an "ethnically homogenous notion of German identity," the creation of a German Volk that can assume responsibility for the past. ${ }^{62}$ Future studies might, as a result, not only have to address the question of what Holocaust memory might mean to the descendants of former "guest workers" and to Syrian, Eritrean, or Afghan refugees. ${ }^{63}$ Such studies will also have to deepen our understanding of how the focus on the memory of the Holocaust was more likely to prevent rather than encourage broader discussions of "race" and "racism" in postwar Germany. ${ }^{64}$ In line with the dominant focus on the Federal Republic's success, racism mainly appeared as a "moment from which one progresses" in postwar memory discourse, not as a contemporary reference point for Holocaust memory. ${ }^{65}$ In this sense, the renewed emphasis on the "singularity" of the Holocaust as a result of the Historians' Debate in the 1980s, which has long been

${ }^{58}$ Norbert Frei, Vergangenheitspolitik. Die Anfänge der Bundesrepublik und die NS-Vergangenheit (Munich: C. H. Beck, 1996); Ulrich Herbert, Best. Biographische Studien über Radikalismus, Weltanschaunng und Vernunft, 1903 -1989 (Bonn: J. H. W. Dietz Nachf., 1996); Bert-Oliver Manig, Die Politik der Ehre. Die Rehabilitierung der Berufsoldaten in der frühen Bundesrepublik (Göttingen: Wallstein, 2004).

${ }^{59}$ Stephan A. Glienke, Volker Paulmann, and Joachim Perels, "Einleitung," in Erfolgsgeschichte Bundesrepublik? Die Nachkriegsgesellschaft im langen Schatten des Nationalsozialismus, ed. Volker Paulmann, Stephan A. Glienke, and Joachim Perels (Göttingen: Wallstein, 2008), 9. For an example of this, see Neil Gregor, Haunted City: Nuremberg and the Nazi Past (New Haven, CT: Yale University Press, 2008)

${ }^{60}$ Christian Mentel and Niels Weise, Die zentralen deutschen Behörden und der Nationalsozialismus. Stand und Perspektiven der Forschung (Munich/Potsdam: Institut für Zeitgeschichte and Zentrum für Zeithistorische Forschung, 2016).

${ }^{61}$ Rita Chin, The Guest Worker Question in Postwar Germany (New York: Cambridge University Press, 2007), 239-40.

${ }^{62}$ Michael Rothberg and Yasemin Yildiz, "Memory Citizenship: Migrant Archives of Holocaust Rememberance in Contemporary Germany," Parallax 17, no. 4 (2011): 35.

${ }^{63}$ See the essays in Viola B. Georgi and Rainer Ohliger, eds., Crossover Geschichte. Historisches Bewusstsein Jugendlicher in der Einwanderungsgesellschaft (Hamburg: Körber Stiftung, 2009); Damani J. Partridge, "Holocaust Mahnmal: Monumental Memory amidst Contemporary Race," Comparative Studies in Sociey and History 52, no. 4 (2010): 820-50.

${ }^{64}$ Meng, "Silences about Sarrazin's Racism"; Chin, "Thinking Difference in Postwar Germany."

${ }^{65}$ Partridge, "Holocaust Mahnmal," 836. 
considered a cultural victory for progressive Holocaust memory, may be due for reevaluation. It was precisely the emphasis on the "singularity" of the Holocaust that enabled the "assertion of complete incommensurability of anti-Semitism and other forms of racism," as Michael Rothberg and Yasemin Yildiz have argued. ${ }^{66}$ How to retain the historical specificity of Jewish victimhood yet also expand the contemporary relevance of the Holocaust to all forms of racism and ethnic cleansing appears to constitute a central commemorative task for the twenty-first century. ${ }^{67}$

The emphasis on writing West German history as a Belastungsgeschichte also came to encompass the after-effects of unprecedented active and passive experiences of violence, especially during the final year of the war. ${ }^{68}$ The Federal Republic bore the "stigma of violence" from the very beginning, as Michael Geyer has argued. ${ }^{69}$ The history of the Federal Republic as the history of the Nachkrieg (postwar) era thus brought into focus the long-term reverberations of wartime experiences. It revealed the prevalence of mentalities and psychological conditions in postwar society that were difficult to incorporate into the forward looking, achievement-oriented society of the economic miracle, yet that nevertheless formed its subterranean and always present unconscious. ${ }^{70}$ Historians are increasingly beginning to reconstruct an imagined history of West Germany that accompanied and sometimes counteracted the Federal Republic's gradual democratization and liberalization. This is a history of collective anxieties and ongoing nightmares, of beliefs in rumors, magic, miracles, and wandering ghosts. ${ }^{71}$ This history often manifested itself only indirectly or implicitly, but it remained present below the surface of postwar stabilization and increasing prosperity. The literary critic Hans-Ulrich Gumbrecht has characterized this predicament as a condition of "latency" in post-1945 Germany, whereas Philipp Felsch and Frank Witzel sought to

\footnotetext{
${ }^{66}$ Rothberg and Yildiz, "Memory Citizenship," 38.

${ }^{67} \mathrm{On}$ the link between Holocaust memory and decolonization, see Michael Rothberg, Multidirectional Memories: Remembering the Holocaust in the Age of Decolonization (Palo Alto, CA: Stanford University Press, 2009); also see Charles S. Maier, "Consigning the Twentieth Century to History: Alternative Narratives for the Modern Era," American Historical Review 105, no. 3 (2000): 825-29.

${ }^{68}$ Frank Biess and Robert G. Moeller, eds., Histories of the Aftermath: The Legacies of the Second World War in Europe (New York: Berghahn, 2010); Pertti Ahonen, "Germany and the Aftermath of the Second World War," Journal of Modern History 89, no. 2 (2017): 355-87.

${ }^{69}$ Michael Geyer, "Das Stigma der Gewalt und das Problem der nationalen Identität," in Von der Aufgabe der Freiheit. Politische Verantwortung und bürgerliche Gesellschaft im 19. und 20. Jahrhundert. Festschrift für Hans Mommsen zum 5. November 1999, ed. Lutz Niethammer, Christian Jansen, and Bernd Weisbrod (Berlin: Akademie Verlag, 1995), 673-98.

${ }^{70}$ The reverberations expressed themselves, for example, in food consumption; see Alice Weinreb, Modern Hungers: Food and Power in Twentieth-Century Germany (New York: Oxford University Press, 2017); see also the discussion of the "war children" in Lu Seegers and Jürgen Reulecke, eds., Die "Generation der Kriegskinder." Historische Hintergründe und Erfahrungen (Giessen: Psychosozial, 2009). See also Klaus Naumann, ed., Nachkrieg in Deutschland (Hamburg: Hamburger Edition, 2001); Frank Biess, Homecomings: Returning POWs and the Legacies of Defeat in Postwar Germany (Princeton, NJ: Princeton University Press, 2006); Lu Seegers, "Vati blieb im Krieg." Vaterlosigkeit als generationelle Erfahrung im 20. Jahrhundert. Deutschland und Polen (Göttingen: Wallstein, 2013); Svenja Goltermann, The War in their Minds: German Soldiers and their Violent Pasts in West Germany (Ann Arbor: University of Michigan Press, 2017).

${ }^{71}$ Monica Black, "Miracles in the Shadow of the Economic Miracle: The 'Supernatural '50s' in West Germany," Journal of Modern History 84, no.4 (2012): 833-60; Goltermann, The War in Their Minds, 2937, passim; Frank Biess, Die Republik der Angst. Eine andere Geschichte der Bundesrepublik (Reinbek: Rowohlt, 2019).
} 
capture it with the idea of a "BRD Noir."72 As in the films noirs of the 1930s and 1940s, the ordinary and prosperous life of the postwar period functioned as a façade concealing the underlying abyss. This history of West German fears and fantasies brings into view the dramatic and highly contingent aspects of postwar history that the somewhat predictable nature of dominant narratives has tended to obscure. ${ }^{73}$

It is precisely this contrast between the imagined and the "real" history of the Federal Republic that strikes us as a productive starting point for rethinking its history. Caitlin Murdock's article on popular fears of radiation during the 1950s and 1960s reveals the extent to which intense anxieties accompanied the rapid modernization of West Germany. A serious consideration of such anxieties undermines an overtly teleological narrative of modernization, and it brings into focus the persistent insecurities, doubts, and fears that went along with that process. Contrary to established narratives, which locate such skepticism toward modernity in the 1970s "after the boom," Murdock illustrates the importance of such sentiments in an earlier period and thus contributes to a different genealogy of antinuclear activism and critical environmental consciousness.

The attention to the uncanny or, for lack of a better word, "irrational" aspects of postwar history stands in contrast to the frequent emphasis on an (often explicitly or implicitly male) Western, rational, enlightenment subject as the main agent in the process of democratization, liberalization, and Westernization. After all, only such rational subjects would have been capable of the "learning process" that Konrad Jarausch sees at the heart of the recivilization of the Federal Republic. ${ }^{74}$ Rather than positing the existence of such "rational subjects" as a given, the history (or, in Foucauldian terms, the genealogy) of democratic selves has emerged as another fruitful field for new narratives of the Federal Republic. ${ }^{75}$ It relates the macrohistory of democratization to the microhistory of subjective norms and practices that were conducive for forging a democratic society - such as, for example, the ability to engage in controversial discussion. ${ }^{76}$ Yet, whereas the standard success narrative of the Federal Republic has tended to associate the notion of individualism with progressive democratization and liberalization, Moritz Föllmer has highlighted the "intrinsic ambivalence" of individualism and its historical compatibility with both democracy and dictatorship. ${ }^{77}$ Histories of subjectivity do not necessarily have to regress to teleological narratives of progressive liberalization and increasing individual freedom. As Pascal Eitler and Jens Elberfeld have argued,

\footnotetext{
${ }^{72}$ Hans Ulrich Gumbrecht, After 1945: Latency as Origin of the Present (Palo Alto, CA: Stanford University Press, 2013); Philipp Felsch and Frank Witzel, BRD Noir (Berlin: Matthias \& Seitz, 2016).

${ }^{73}$ Joachim Radkau, Geschichte der Zukunft. Prognosen, Visionen, Irrungen in Deutschland von 1945 bis heute (Munich: Hanser, 2017), 131.

${ }^{74}$ Jarausch, After Hitler, vii, 103-55.

${ }^{75}$ Andreas Reckwitz, Das hybride Subjekt. Eine Theorie der Subjektkulturen von der bürgerlichen Moderne zur Postmoderne (Göttingen: Velbrück Wissenschaft, 2006); Maik Tändler, Das therapeutische Jahrzehnt. Der Psychoboom in den Siebziger Jahren (Göttingen: Wallstein, 2016); Pascal Eitler and Jens Elberfeld, eds., Zeitgeschichte des Selbst. Therapeutisierung-Politisierung-Emotionalisierung (Bielefeld: transcript, 2015). A focus on the history of democratic subjectivity exists for the Weimar Republic but has not been fully developed for the Federal Republic. See Kerstin Barndt, Kathleen Canning, and Kristin McGuire, eds., Weimar Publics/Weimar Subjects: Rethinking the Political Culture of the 1920s (New York: Berghahn, 2010); Moritz Föllmer, Individual and Modernity in Berlin: Self and Society from Weimar to the Wall (New York: Cambridge University Press, 2013).

${ }^{76}$ Nina Verheyen, Diskussionslust. Eine Kulturgeschichte des "besseren Arguments" in Westdeutschland (Göttingen: Vandenhoeck \& Ruprecht, 2010).

${ }^{77}$ Föllmer, Individual and Modernity, 277.
} 
histories of the self seek to transcend the binary poles of success or decline and instead chart the historical genealogy of democratic selves. The gradual decline of external constraints thus complemented new and perhaps no less effective forms of internal discipline and control, often in and through an engagement with therapeutic processes. This development did not necessarily lead to liberation and increasing individualism; it also produced new constraints that were embodied, for example, in the neoliberal "entrepreneurial self."78

Histories of democratic subjectivities would also have to engage anew with oppositional forces in postwar West German society, which dominant narratives often marginalized. For Hans-Ulrich Wehler, opponents of nuclear energy were "not open to rational arguments," and activists of the later peace movement engaged in "hysterical avowals of fear." "T9 Several other syntheses resort to the language of pathology and mental illness in characterizing resistance or opposition to the Federal Republic's relentless march toward the "West." For Edgar Wolfrum, the transformation of values during the 1960s assumed a "more neurotic" character in West Germany than elsewhere; left-wing intellectuals engaged in "rampant cultural pessimism" and "nostalgic memory," and the "nationalist-neutralist left" harbored a "romanticizing, anti-Enlightenment, and anti-Western historical vision [Geschichtsbild]." 80 This is not to say that these interpretations are necessarily wrong. Oppositional movements in the West did indeed call into question basic assumptions of Western modernity from the 1970s onward. But the recourse to a language of psycho-pathological deviancy suggests that these oppositional movements have not yet been fully historicized or analyzed on their own terms, but only in relation to a normative model of Enlightenment rationalism. ${ }^{81}$ Like "individualism," "rationality" is, after all, a deeply historical category thoroughly linked to Cold War culture, and it therefore cannot function as a universal yardstick by which to evaluate historical processes. ${ }^{82}$

It is, in fact, well worth revisiting the West German protest movements that challenged the transformation processes in the Federal Republic, as Joachim Häberlen and Christina von Hodenberg do in their contributions. It is arguably the intensity and longevity of the various protest movements of the postwar period that is distinctive for the Federal Republic. The standard narratives of success tend to integrate these movements through an "ironic" emplotment. ${ }^{83}$ That is, they argue that these movements inadvertently promoted exactly the "Westernization," "Americanization," or "liberalization" that they claimed to reject. ${ }^{84}$ This argument depends on divorcing the protagonists' stated intentions from their longterm cultural effects. These interpretations thus fail to take historical actors seriously on their own terms. They see their protests as being somehow "sublated" (aufgehoben), in a

\footnotetext{
${ }^{78}$ Ulrich Bröckling, Das unternehmerische Selbst. Soziologie einer Subjektivierungsform (Frankfurt/Main: Suhrkamp, 2007).

${ }^{79}$ Wehler, Deutsche Gesellschaftsgeschichte, 61, 250.

${ }^{80}$ Wolfrum, Die geglückte Demokratie, 253, 391, 395.

${ }^{81}$ This depiction of oppositional forces as irrational and pathological also stands in a long tradition of portraying the Nazi dictatorship in similar terms. Wolfrum, for example, approvingly cites Hans-Peter Schwarz's assertion that a "completely hysterical people" during the Third Reich managed to accomplish almost immediately a "civilized peace" in the Federal Republic. See ibid., 185.

${ }^{82} J u d y$ L. Klein, Paul Erickson, Lorraine Daston, Rebecca Lemov, Thomas Sturm, and Michael D. Gordin, How Reason Almost Lost Its Mind: The Strange Career of Cold War Rationality (Chicago, IL: University of Chicago Press, 2013).

${ }^{83}$ For Hayden White's “emplotments," see Joachim Häberlen's contribution to this special issue.

${ }^{84}$ Winkler, Der lange Weg nach Westen, 252-53; Jarausch, After Hitler, 179-81.
} 
Hegelian sense, in the emergence of a more progressive and liberal society in West Germany. They therefore tend to subordinate the oppositional energies and disruptive potentials of these protests to the master narrative of the Federal Republic's eventual arrival in the West. By contrast, Häberlen emphasizes the extent to which nonconformist practices and ideas popular in the alternative milieu of the 1970s resisted incorporation into any narrative. The goal here is not to fit protest movements into preexisting consensual narratives, but rather to highlight the disruptive and subversive potential of protest movements for both history and historiography.

If protest movements would benefit from reconsideration, the same holds true for environmental history approaches to the history of the Federal Republic. To be sure, a number of classic themes in the field, such as nature conservation, pollution, environmental protection policies, changing environmental sensibilities, and protest movements have all been widely explored in the West German context. ${ }^{85}$ But even the potential of environmental approaches to connect West and East German history in a relational framework remains underutilized. ${ }^{86}$ Because the field of environmental history has gone global and even planetary, historians of the Federal Republic have their work cut out for them when it comes to assessing how West Germany fits into the "Great Acceleration," i.e., the escalation since around 1950 of human impact on a global scale on the Earth and the biosphere. ${ }^{87}$ Isolating one country's influence and effects on a variety of earth-system indicators, such as ocean acidification or stratospheric ozone, may be statistically impossible beyond a rough approximation. Still, reconsidering postwar economic recovery in the context of the Great Acceleration would presumably yield a very different narrative of the "economic miracle" than one that focuses on growth rates, reconstructed housing, receding unemployment, and increasing affluence. ${ }^{88}$ Instead, West Germany's reconstruction and subsequent boom years would center on carbon

\footnotetext{
${ }^{85}$ Franz-Josef Brüggemeier, Blauer Himmel über der Ruhr. Geschichte der Umwelt im Ruhrgebiet, 1840-1990 (Essen: Klartext, 1992); Monika Bergmeier, Umweltgeschichte der Boomjahre 1949-1973. Das Beispiel Bayern (Münster: Waxmann, 2002); Kai F. Hünemörder, Die Frühgeschichte der globalen Umweltkrise und die Formierung der deutschen Umweltpolitik, $1950-1973$ (Stuttgart: Steiner, 2004); Jens Ivo Engels, Naturpolitik in der Bundesrepublik. Ideenwelt und politische Verhaltensstile in Naturschutz und Umweltbewegung, 1950-1980 (Paderborn: Schöningh, 2006); Hans-Werner Frohn and Friedemann Schmoll, eds., Natur und Staat. Staatlicher Naturschutz in Deutschland 1906-2006 (Bonn: Bundesamt für Naturschutz, 2006); Sandra Chaney, Nature of the Miracle Years: Conservation in West Germany, 1945-1975 (New York: Berghahn, 2008); Ute Hasenöhrl, Zivilgesellschaft und Protest. Eine Geschichte der Naturschutz- und Umweltbewegung in Bayern 1945-1980 (Göttingen: Vandenhoeck \& Ruprecht, 2008); Frank Uekötter, The Greenest Nation? A New History of German Environmentalism (Cambridge, MA: MIT Press, 2015); Birgit Metzger, "Erst stirbt der Wald, dann du!" Das Waldsterben als westdeutsches Politikum, 1978-1986 (Frankfurt/Main: Campus, 2015).

${ }^{86}$ Frank Uekötter, "Entangled Ecologies: Outlines of a Green History of Two or More Germanys," in Bösch, A History Shared and Divided, 147-90; Astrid M. Eckert, West Germany and the Iron Curtain: Environment, Economy, and Culture in the Borderlands (New York: Oxford University Press, forthcoming 2019).

${ }^{87}$ Will Steffen, Paul Crutzen, and John R. McNeill, "The Anthropocene: Are Humans Now Overwhelming the Great Forces of Nature?," Ambio 36, no. 8 (2007): 614-21; John R. McNeill and Peter Engelke, The Great Acceleration: An Environmental History of the Anthropocene since 1945 (Cambridge, MA: Harvard University Press, 2016). For a discussion of the terminology and the earlier concept "1950s Syndrome," see Christian Pfister, "The '1950s Syndrome' and the Transition from Slow-Going to a Rapid Loss of Global Sustainability," in The Turning Points of Environmental History, ed. Frank Uekötter (Pittsburgh, PA: University of Pittsburgh Press, 2010), 90-118.

${ }^{88}$ For this familiar narrative, see, e.g., Wehler, Gesellschaftsgeschichte, 48-88; Wolfrum, Die geglückte Demokratie, 75-95; Conze, Die Suche nach Sicherheit, 157-80.
} 
emissions, intensifying land use, shrinking biodiversity, and the environmental footprint of long-distance tourism, among other developments and trends. The exponential rise in car ownership also looks different if seen as an indicator of recovery and regained leisure-or as a cause of smog and atmospheric ozone. The mainstreaming of the analysis of energy systems and politics, though mostly centered on the period since the 1970s, is a promising narrative shift. 89

Finally, the history of the Federal Republic looks different if it is written across the caesura of 1989-1990 without using unification as a vanishing point. As Eckart Conze has remarked, the post-1989 period can no longer be treated merely as an epilogue, now that the history of the unified country accounts for more than a third of the Federal Republic's existence. ${ }^{90}$ It is significant that Conze's own history of the Federal Republic, published at the height of the worldwide recession in 2009, has a somewhat more skeptical tone, viewing that history as a history of the "origins of contemporary problems," which, "by definition, means that it cannot be a success history." "91 Jennifer Allen forcefully argues "against the 1989-1990 ending myth," which, she believes, relies on two interpretative assumptions: "first, a temporal sensibility based on a belief in the progressive development of society and, second, a conception of identity and difference understood in Manichaean Cold War terms." Just how influential the 1990 caesura remains also becomes apparent in those studies that take it as a starting point - and thereby run the risk of turning it into an origin story for unified Germany. ${ }^{92}$ Yet, there are few attempts to see what were to happen if we were to restore contingency and write "across" the 1990 caesura. ${ }^{93}$ By leaving the Cold War framework behind, it will likely become apparent that many issues, such as modes of labor and social security, environmental concerns, migration and mobility, education, sports, media, and consumption, all follow an intrinsic logic that was never exclusively determined by either the East or West German system, even if each state's ideological, political, and economic order no doubt influenced those developments for a certain period of time. ${ }^{94}$

Those established narratives in which the post-1990 years still appear as an epilogue tend to characterize that time period with reference to terms such as normalcy and normalization. ${ }^{95}$ This emphasis on "normalcy" appears to be in keeping with the general framework of

\footnotetext{
${ }^{89}$ Rüdiger Graf, Oil and Sovereignty: Petro-Knowledge and Energy Policy in the United States and Western Europe in the 1970s, trans. Alex Skinner (New York: Berghahn, 2018); Craig Morris and Arne Jungjohann, Energy Democracy: Germany's Energiewende to Renewables (Switzerland: Palgrave Macmillan, 2016); Stephen G. Gross, "Decoupling and the New Energy Paradigm in West Germany, 1973-1986," Central European History 50, no. 4 (2017): 514-46.

${ }^{90}$ Conze, Die Suche nach Sicherheit, 13.

${ }^{91}$ Ibid., 12. His framework is the search for "security" in various forms, yet the ensuing narrative frequently suggests that this sense of security had mostly been achieved. The narrative thus becomes almost inadvertently yet another version of the success story.

${ }^{92}$ Großbölting and Lorke, Deutschland seit 1990.

${ }^{93}$ See the ongoing project by Kerstin Brückweh on the "long history of the Wende," which consciously moves beyond 1989 but restricts itself to East German transformations: http://zzf-potsdam.de/de/forschung/linien/die-lange-geschichte-der-wende-lebenswelt-systemwechsel-ostdeutschland-vor-wahrend. See also Eckert, West Germany and the Iron Curtain.

${ }^{94}$ For a discussion of these issues in both German states, carried out in a relational but not parallel framework that pursues interdependencies and mutual influences while minding obvious differences, see Bösch, A History Shared and Divided. The various topics are then developed up to the year 2000.

${ }^{95}$ Conze, Suche nach Sicherheit, 109; Wolfrum, Die geglückte Demokratie, 16; Winkler, Der lange Weg nach Westen, 2:655-56.
} 
Westernization and with assertions that the Federal Republic had become a "normal nation," that Germans are "not peculiar, either in a good or a bad sense," that the Federal Republic is neither "a model to emulate" nor an "alarming backward political slacker," that it exudes a sense of "competent normalcy." 96 Just as the recurring announcement of an "end to the postwar era" throughout the history of the Federal Republic can be read as an indication of the persistent consequences of the war, the frequent insistence on the accomplishment of "normalcy" might point to its actual absence. ${ }^{97}$ After all, one may well consider the constant need to invoke "normalcy" as abnormal. "Normalcy" often denoted the country's arrival in the fold of Western liberal democracies. But this "model," toward which the Federal Republic allegedly gravitated, appears to be undergoing dramatic changes in the present. "Normalcy" thus appears as an inadequate, vague, and ultimately misleading label for a yet-to-be written history of the Berlin Republic. Its invocation obscures a conceptual problem of writing the history of the present time, namely, the contingency and uncertainty of the future. ${ }^{98}$ New narratives of the Federal Republic would thus do well not just to transcend the caesura of 1989-1990, but also to move away from an ill-defined concept of Western "modernity" as the vanishing point for the history of the Federal Republic.

All historical narratives have advantages and disadvantages. They allow us to bring into focus certain aspects of the past while obscuring or marginalizing others. The established narratives of the Federal Republic have succeeded in highlighting the forces that propelled Germany from a post-dictatorial society into an internationally reliable, prosperous, liberal-democratic, "Western" one. They have also highlighted the achievements and shortcomings of the Federal Republic's attempts to come to terms with a violent and destructive past. Yet, regardless of whether this has prompted self-reflection, these narratives have often adopted teleological models of success. They have rarely questioned the status of Western liberalism as a normative model and have generally failed to address the blind spots, internal contradictions, and exclusions that were always inherent in that tradition. Finally, they have yet to incorporate the post-1989 period, but instead use an ill-defined "normalcy" as the telos of post-unification Germany.

As the contributions in this special issue make clear, a search for new narratives for the history of the Federal Republic is currently underway. It is neither likely nor desirable that this search yield yet another consensus narrative. But it might provide an ever more complex and nuanced picture of the Federal Republic as a historical formation that, during the almost seventy years of its existence, witnessed dramatic transformations and deep sociocultural changes, yet managed to avoid the violence and political ruptures of previous periods of German history. With that in mind, this special issue offers a glimpse of possible new directions for writing the history of the Federal Republic in the twenty-first century.

University of California, San Diego

EMORY UNIVERSITY

\footnotetext{
${ }^{96}$ Wolfrum, Die geglückte Demokratie, 16; Jarausch, "The Federal Republic at Sixty," 25.

${ }^{97}$ Klaus Naumann, "Die Frage nach dem Ende. Von der unbestimmten Dauer der Nachkriegszeit," Mittelweg 36 8, no. 1 (1999): 21-32.

${ }^{98} \mathrm{On}$ this problem, see Rüdiger Graf, "Die Unkenntnis der Zukunft und der Zukunftsbezug der Zeitgeschichte," in Die Zukunft des 20. Jahrhunderts. Dimensionen der historischen Zukunftsforschung, ed. Lucian Hölscher (Frankfurt/Main: Campus, 2017), 303-19.
} 